them to bridge even a short spell on the streets.

It is a marvellously productive yet cruel system, comparable with child labour in both respects. The difference is that the victims of the postdoctoral system in the United States are no longer children, but grown men and women, often with families and family responsibilities. Now that the traditional reward for consecutive spells as a postdoctoral fellow - a tenured position at some academic institution is itself receding, it would be only natural if trained researchers let their ambitions embrace other goals, in industry or even commerce. The remedy is one in any case required by natural justice: a more civilized way of dealing with the careers of the non-commissioned officers of research. Thirtyseven, after all, is hardly a reasonable definition of youth. Einstein had done all his important work by that age.

\section{Regulating embryology}

A premature ban on the use of fetal oocytes in the treatment of infertility is a needless mistake.

SHOULD human oocytes taken from an aborted human fetus be used, after fertilization, in the treatment of infertility? The answer is unambiguous, and "No!". Despite the present shortage of eggs for use in infertility treatment, the use of eggs from aborted fetuses would be improper while so little is known of the reasons why the number of surviving oocytes in the human ovary declines so drastically (by a factor of $100,000)$ between birth and adulthood. Is this a random process designed to reduce the metabolic cost of being female, or nature's built-in mechanism for genetic screening and the elimination of disadvantageous eggs? While that question is undecided, the use of fetal oocytes would be potentially dangerous, and therefore wrong. And some time must pass before there is an answer.

That is part of the background to the publication last week of a new policy statement by Britain's hyperactive Human Fertilization and Embryology Authority, which has statutory responsibility for licensing fertility treatment (including artificial insemination) and research. The new statement deals with the possible use of eggs from three sources: aborted female fetuses, the cadavers of adult women and the ovaries of women who are alive and who volunteer to donate ovarian tissue (see page 241). On the last, the committee asks only that there should be full informed consent (which entails that the donors should be adult), on the second, it advocates a system of donor cards (as for other organs) which has not yet been developed, but it then goes on to declare a ban on the use of fetal oocytes except in research.

These policy decisions are sheer busybodyness. The use of adult ovaries in the manner the committee recommends is covered by existing legislation (including that under which the committee itself exists). The committee did not need a "policy decision" to regulate them. It would also have been well within its present competence to have refused licences to those seeking to use fetal oocytes for the treatment of infertility until there is a better understanding of the biology of the natural attenuation of the oocyte population. That, indeed, would have been the time to have launched the consultation exercise on which the committee has laboured for six months, and whose most memorable product appears to have been a write-in campaign by anti-abortionists. The danger in this needless fuss is that the committee's claim on seriousness will be undermined (see Nature 361, 283; 1993).

\section{Eastern jobs go west}

German reunification continues to exact a high price in the east, but one that may be worth paying.

GERMANY is paying a high price for unification, not only through the government's increased load of public debt, but in the repeated reminders to those in the six new Länder of the east that the old German Democratic Republic collapsed into the arms of West Germany three years ago on terms determined largely in the west. The reorganization of eastern universities on western lines was one of the conditions of reunification. There have been just complaints at the tests of political correctness to which eastern academics were subjected. Now, many east German academics have lost their jobs in open competition with people they will regard as carpetbaggers from the west (see page 240).

The hope must be that this latest humiliation will not be the divisive influence it may seem. Although the eastern economy still lags behind that of western Germany, Germany is now a single political entity, with all that implies for the present and the future. A generation from now, there is every chance that people will have forgotten the old division.

In any case, the competition for university posts appears to have been conducted on merit only. Those who have lost their posts will not lose their pension rights. And in the long run it will help the east that a number of academics from western Germany have thrown in their lot with eastern universities. (They are far outnumbered by the commercially minded people seeking to make their fortunes to the east.) Whatever their strengths in scholarship and research, universities in the east can only benefit from a modest influx of people used to the argumentative and free-thinking ways of the traditional German university. And while the numbers may be small, go-getting academics from the west could help to unlock sources of research funds not yet tapped.

\section{One-day conferences}

A Nature meeting, Genetics in Europe now, will be held in Berlin on Friday 30 September 1994 at the Brandenberg Akademie, and the cost is DM195 or $£ 75$ (plus VAT).

A meeting in Paris, What is distinctive about European sci ence?, will be held on Wednesday 26 October 1994 at the Ecole Normale Supérieure. The cost is FFr675 or $£ 75$ (plus VAT).

Payment may be made by cheque (payable to Macmillan Subscriptions Ltd) or credit card. For further details of either meeting, or to reserve places, please write, telephone or fax to Pippa Burnett, Nature Conferences Office, 4 Little Essex Street, London WC2R 3LF, UK; telephone +44 718366633 ext. 2593; fax +44713795417 . 